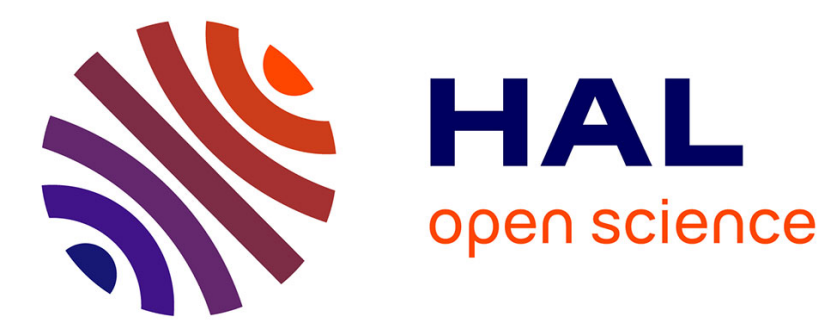

\title{
On the influence of water traces on the acidity measurement of amorphous aluminosilicates
}

Juliette Blanchard, Jean-Marc Krafft, Colin Dupont, Céline Sayag, Toshikazu

Takahashi, Hiroyuki Yasuda

\section{- To cite this version:}

Juliette Blanchard, Jean-Marc Krafft, Colin Dupont, Céline Sayag, Toshikazu Takahashi, et al.. On the influence of water traces on the acidity measurement of amorphous aluminosilicates. Catalysis Today, 2014, 226, pp.89-96. 10.1016/j.cattod.2013.10.054 . hal-01226880

\section{HAL Id: hal-01226880 https://hal.sorbonne-universite.fr/hal-01226880}

Submitted on 25 Feb 2016

HAL is a multi-disciplinary open access archive for the deposit and dissemination of scientific research documents, whether they are published or not. The documents may come from teaching and research institutions in France or abroad, or from public or private research centers.
L'archive ouverte pluridisciplinaire HAL, est destinée au dépôt et à la diffusion de documents scientifiques de niveau recherche, publiés ou non, émanant des établissements d'enseignement et de recherche français ou étrangers, des laboratoires publics ou privés. 


\section{On the influence of water traces on the acidity measurement of}

\section{amorphous aluminosilicates}

Juliette Blanchard ${ }^{*}$, a , Jean-Marc Krafft ${ }^{\mathrm{a}}$, Colin Dupont ${ }^{\mathrm{a}}$, Céline Sayag ${ }^{\mathrm{a}}$, Toshikazu Takahashi $^{\mathrm{b}}$, Hiroyuki Yasuda ${ }^{\mathrm{b}}$

${ }^{a}$ UPMC Univ Paris 06, UMR 7197, Laboratoire de Réactivité de Surface, F-75005, Paris, France, and CNRS, UMR 7197, Laboratoire de Réactivité de Surface, F-75005, Paris, France. ${ }^{b}$ Research Institute for innovation in Sustainable Chemistry, AIST, Tsukuba Central 5, 1-1-1, Japan

\section{I.1. Abstract}

For the measurement of their acidity, amorphous aluminosilicates are beforehand treated at temperature of $450^{\circ} \mathrm{C}$ or higher in order to remove water adsorbed on their surface. We will show in this study that, during the standard course of an acidity measurement by low temperature $\mathrm{CO}$ adsorption, traces of water present in the setup may perturb the acidity measurement by desorbing from the setup and adsorbing on the sample. We will also demonstrate that the interaction of water occurs on mild and strong Lewis sites and leads to the detection of stronger Brønsted sites than those natively present in the amorphous aluminosilicate. We will finally propose an experimental procedure that allows avoiding the adsorption on water on the sample and will clearly identify the position of the band associated with $\mathrm{H}_{2} \mathrm{O}$ and $\mathrm{D}_{2} \mathrm{O}$ adsorbed on Lewis sites before and after addition of $\mathrm{CO}$.

\section{I.2. Highlights}

Unwanted $\mathrm{H}_{2} \mathrm{O}$ adsorption modifies acidity distribution in standard conditions A procedure is proposed to suppress water readsorption during acidity measurement

\footnotetext{
${ }^{1}$ To whom correspondence should be addressed. E-mail: juliette.blanchard@upmc.fr. Tel: + 33144274914. Fax: + 33144276033
} 
First time report of the position of the bands of $\mathrm{D}_{2} \mathrm{O}$ adsorbed on undercoordinated $\mathrm{Al}$ Water adsorption on Lewis sites leads to Brønsted sites stronger than the native ones

\section{Keywords}

Brønsted acidity, Lewis acidity, amorphous silica-alumina, ASA, CO adsorption, BAS,

\section{LAS}

\section{I.3. Introduction}

Many chemical processes in oil refining, petrochemistry and fine chemicals production rely on heterogeneous acid catalysts. Silica-alumina materials, which combine high surface areas and Lewis and Brønsted acidic properties, are widely used in these applications. These materials can be divided into two families: 1) zeolites which are crystalline and microporous and 2) amorphous silica-aluminas (ASA) which are mesoporous. Zeolites contain mainly Brønsted sites arising from the presence of Si-OH-Al bridges. In ASA, the exact nature of the Brønsted acid sites is more obscure: a small fraction of $\mathrm{Si}-\mathrm{OH}-\mathrm{Al}$ bridges (as in zeolites [1]) and/or silanol of enhanced acidity by a neighbouring Lewis aluminium (i.e. $\{\equiv \mathrm{Si}-\mathrm{OH} ; \square \mathrm{Al} \equiv\}$ pair $[2]$ ) and/or pseudo-bridging silanols (i.e. an $\{\equiv \mathrm{Si}-\mathrm{OH}$; $\square \mathrm{Al} \equiv\}$ pair that becomes $\mathrm{Si}_{-}^{-}-\mathrm{Al}, \mathrm{BH}^{+}$in presence of a basic molecule $\mathrm{B}[3,4,5]$. ASA contain also Lewis acid sites, associated with the presence of undercoordinated aluminium. The transformation of Lewis acid sites to Brønsted acid sites in presence of water has been reported almost fifty years ago [6] and used for example to determine the absorption coefficient of pyridine chemisorbed on Brønsted and Lewis sites [7]. However, the nature and strength of the resulting Brønsted sites has only very recently been investigated by computational and/or spectroscopic tools [8-10] and still needs clarification.

Many efforts have recently been devoted to the study of the nature and strength of the acid sites of ASA by spectroscopic characterization of adsorbed basic probe molecules $[2,11$ - 
13], with the general purpose to understand the origin of the lower acidity of ASA compared to zeolite. Among the molecules used as acidity probes (either strong bases such as pyridine, lutidine, $\mathrm{NH}_{3} \ldots$, or weak bases such as n-hexane or benzene...), carbon monoxide (CO) has received a great deal of attention due to its suitability for both qualitative and semiquantitative analysis. Its small size, softness (in terms of basicity), non-reactivity (at low temperature) and sensitivity make it ideal for the investigation of samples with both Brønsted and Lewis acid sites. $\mathrm{CO}$ adsorption on acid sites leads to a high frequency shift of the $\mathrm{C}-\mathrm{O}$ stretching mode. The larger the CO shift (compared to free CO located at $2139 \mathrm{~cm}^{-1}$ ) the stronger the acid site. Moreover, the adsorption of $\mathrm{CO}$ on a Brønsted acid site leads to a shift of the $v(\mathrm{OH})$ (low frequency shift) band of several tens/hundreds of $\mathrm{cm}^{-1}$ and the importance of this shift is also related to the strength of the acid site.

We will present results that will demonstrate that, in standard measurements conditions, traces of water present in the setup may adsorb on the Lewis sites and form stronger Brønsted sites than those initially present in the amorphous aluminosilicate. We will also propose an experimental procedure that allows avoiding the adsorption on water on the sample, and clearly identify the position of the band associated with $\mathrm{H}_{2} \mathrm{O}$ and $\mathrm{D}_{2} \mathrm{O}$ adsorbed on Lewis sites before and after addition of $\mathrm{CO}$.

\section{I.4. Experimental}

The ASA sample used for this study was graciously provide by Grace Davison and has the following characteristics: it contains $13 \mathrm{wt} \% \mathrm{Al}_{2} \mathrm{O}_{3}$, has a BET surface area of $575 \mathrm{~m}^{2} \cdot \mathrm{g}^{-1}$ and the total number of Brønsted and Lewis sites, measured by $\mathrm{NH}_{3}-\mathrm{TPD}$, is ca. $400 \mu \mathrm{mol} . \mathrm{g}^{-1}$.

The transmission FTIR spectra of adsorbed CO were collected on a Bruker Vertex 70 spectrometer using a MCT detector (resolution $2 \mathrm{~cm}^{-1}, 64$ scans per spectrum). The in situ setup used for this study has been described in details in [14]. The upper part is used for the pretreatment of the sample and the sample is move from the upper part to the lower part (for 
FTIR measurements) with a magnet attached to the sample holder. The lower part can be cooled down to about $100 \mathrm{~K}$ thanks to a liquid $\mathrm{N}_{2}$ container that surrounds the cell. The selfsupported wafer of about $15 \mathrm{mg} \cdot \mathrm{cm}^{-2}$ was first calcined in situ under $\mathrm{O}_{2}\left(30 \mathrm{~mL} \cdot \mathrm{min}^{-1}\right)$ at 723 or $973 \mathrm{~K}$ and then evacuated under secondary vacuum $\left(5.10^{-6}\right.$ Torr $)$ at this temperature for $1 \mathrm{~h}$. Three procedures have been followed after this pretreament step and prior to the $\mathrm{CO}$ adsorption measurement itself. Standard procedure: the sample wafer is left to cool down to RT under secondary vacuum during $1 \mathrm{~h}$ hour, after what the wafer is lowered to the lower part of the cell which has been cooled down to ca. 100K beforehand (S-723). Fast Cooling procedure: the wafer is directly moved from the upper part (heated either at 723 or at $973 \mathrm{~K}$ ) to the lower part (cooled to 100K): FC-723 and FC-973. Procedure with Water exposure: the sample is either exposed to pulses of $\mathrm{H}_{2} \mathrm{O}$ or $\mathbf{D}_{2} \mathrm{O}$ (ca. $1.5 \mu \mathrm{mol}$ ) or left under static vacuum in the cell overnight. It is then evacuated under secondary vacuum, the temperature is increased to $323 \mathrm{~K}$ and the sample is left $30 \mathrm{~min}$ at this temperature. After that the wafer is quickly lowered to the measurement cell cooled down at ca. 100K (spectra W-723, W-973 and D-973, where $\mathrm{W}$ stand for $\mathrm{H}_{2} \mathrm{O}$ and $\mathrm{D}$ for $\mathrm{D}_{2} \mathrm{O}$ ). For the three procedures, prior to the addition of $\mathrm{CO}$, a He pulse (10 Torr, about $0.7 \mu \mathrm{mol} \mathrm{He}$ ) is added in order to speed up thermal equilibration $[14,15]$. The purpose of this step is to allow the wafer to reach its equilibrium temperature. Indeed, under vacuum, thermal equilibrium is very slow and very difficult to obtain before the addition of the first $\mathrm{CO}$ pulse. The progressive increase in pressure in the cell upon $\mathrm{CO}$ addition will results in a progressive decrease of the temperature of the wafer and therefore a shift of all the infrared peaks. As explained by Trukhan et al. [15], this usually leads, in difference spectra, in distorted peaks and possibly to the appearance of artefact ones. Addition of a small amount of $\mathrm{He}$ increases the pressure in the cell sufficiently to reach thermal equilibrium in a few minutes. Spectra were recorded after addition of each successive CO pulse (6 Torr, $0.45 \mu \mathrm{mol} \mathrm{CO}$ ) and also during the desorption step at $\mathrm{P} \approx 10^{-5}$ mbar. The 
difference spectra reported in this study were obtained by subtracting the spectra of the sample before addition of any $\mathrm{CO}$ pulse from those recorded after adsorption of successive doses of CO.

\section{I.5. Results}

The figure 1 shows the $\mathrm{OH}$ range of the spectra after pretreatment at $723 \mathrm{~K}$ followed by different cooling procedures (Standard S-723, Fast Cooling FC-723, and Water exposure W-723). The differences between FC-723 and W-723 are clearly visible: the spectrum obtained after Fast Cooling only shows the narrow peak associated with free silanols at 3750 $\mathrm{cm}^{-1}$ together with a broad shoulder at ca. $3625 \mathrm{~cm}^{-1}$ associated with hydrogen bounded silanols, whereas the sample obtained after water exposure present three extra bands at 3687 , 3609 and $1606 \mathrm{~cm}^{-1}$. These positions are shifted but consistent with antisymmetric and symmetric stretching and with bending mode of water in the gas phase $\left(\mathrm{v}_{\mathrm{as}}\left(\mathrm{OH}_{2}\right)=3756 \mathrm{~cm}^{-1}\right.$ $\left.v_{\mathrm{as}}\left(\mathrm{OH}_{2}\right)=3656 \mathrm{~cm}^{-1} \delta\left(\mathrm{OH}_{2}\right)=1595 \mathrm{~cm}^{-1}\right)$. IR bands have been previously observed at similar position $\left(3697,3611,1605 \mathrm{~cm}^{-1}\right)$ by Garrone et al. on the difference spectra after CO adsorption of Al-MCM-41 materials and assigned respectively to $v_{\mathrm{as}}\left(\mathrm{OH}_{2}\right), \mathrm{v}_{\mathrm{s}}\left(\mathrm{OH}_{2}\right)$ and $\delta\left(\mathrm{OH}_{2}\right)$ of water adsorbed on the Lewis sites (undercoordinated $\mathrm{Al}^{3+}$ ) of silica-aluminas [8]. These values are also close to values reported for similar systems (3686 and $3616 \mathrm{~cm}^{-1}$ for $v_{\text {as }}\left(\mathrm{OH}_{2}\right), v_{\mathrm{s}}\left(\mathrm{OH}_{2}\right)$ of $\mathrm{H}_{2} \mathrm{O}$ in $\mathrm{Ni}^{+}\left(\mathrm{H}_{2} \mathrm{O}\right)$, [16]). This is nevertheless the first observation of these bands at RT on the spectrum before $\mathrm{CO}$ adsorption. The spectrum after the Standard cooling procedure (S-723) shows no visible difference with the one measured after the Fast Cooling procedure (FC-723).

The difference spectra of FC-723, W-723 and S-723 after addition of 1, 2 and 11 doses of $\mathrm{CO}(0.45,0.9,5 \mu \mathrm{mol}$ of $\mathrm{CO})$ are shown on figure 2 . The last amount was chosen as it corresponds to a saturation of the strong and mild Lewis and Brønsted sites for all samples. 
The three wavenumber ranges of interest $\left(3800-3200 \mathrm{~cm}^{-1}\right.$ for $v(\mathrm{OH})$ and $v(\mathrm{CO} \ldots \underline{\mathrm{OH}}), 2300$ $2100 \mathrm{~cm}^{-1}$ for $v(\mathrm{CO})$ and $v(\underline{\mathrm{CO}} \ldots \mathrm{OH})$ and $1700-1500 \mathrm{~cm}^{-1}$ for $\left.\delta\left(\mathrm{H}_{2} \mathrm{O}\right)\right)$ have been displayed with the same $\mathrm{Y}$ scale but various $\mathrm{X}$ scales in order to facilitate the observation of the IR bands.

The spectra of the sample after Fast Cooling procedure (figure 2 (a) FC-723, dotted line) shows the bands characteristic of a silica-alumina sample: in the $v(\mathrm{CO})$ range the two bands at 2231 and $2190 \mathrm{~cm}^{-1}$ are characteristic of CO adsorbed respectively on strong and mild Lewis sites whereas the third band at $2172 \mathrm{~cm}^{-1}$ could be associated with $\mathrm{CO}$ in interaction with either a Lewis or a Brønsted sites. However, the adsorption of $\mathrm{CO}$ on Brønsted sites being ascertained by the modifications in the $v(\mathrm{OH})$ range, it must necessarily be due to Brønsted sites. Its position is characteristic of relatively mild average Brønsted acidity. In the $v(\mathrm{OH})$ range, two bands are observed at 3718 (negative band) and $3550 \mathrm{~cm}^{-1}$. As they grow simultaneously with $\mathrm{CO}$ loading, they can be assigned to the $v(\mathrm{OH})$ and $v(\mathrm{CO} \ldots \mathrm{OH})$ of the same Brønsted sites. Their position and the shift of the $v(\mathrm{OH})(\Delta v(\mathrm{OH})=-$ $168 \mathrm{~cm}^{-1}$ ) with $\mathrm{CO}$ are characteristic of mild Brønsted sites and, according to the correlation established by Crepeau et al, should correspond to a $v(\mathrm{CO} . . \mathrm{OH})$ band at ca. $2164 \mathrm{~cm}^{-1}$ [2] These sites are often associated with silanols in close vicinity with an Al Lewis site [2]. A shoulder on the right side of the band at $3550 \mathrm{~cm}^{-1}$, whose position is difficult to determine precisely (ca. $3480-3450 \mathrm{~cm}^{-1}$ ), indicates the presence of Brønsted sites of stronger acidity. Increasing the $\mathrm{CO}$ loading to $0.9 \mu \mathrm{mol}$, leads, in the $\mathrm{CO}$ range, to an increase in the intensities of the $v(\mathrm{CO})$ bands associated with CO on mild and strong Lewis sites $\left(2231\right.$ and $\left.2190 \mathrm{~cm}^{-1}\right)$ and of the $v(\mathrm{CO} \ldots \mathrm{OH})$ band associated with Brønsted sites. A shoulder becomes visible on the right side of this band that can be assigned to $\mathrm{CO}$ interacting with Brønsted sites of very weak acidity. The corresponding bands in the $v(\mathrm{OH})$ range are located at $3745 \mathrm{~cm}^{-1}$ (negative band) 
and at $3650 \mathrm{~cm}^{-1}$. These bands are generally associated with silanols on the surface of silicalike domains [2]. After addition of $5 \mu \mathrm{mol}$ of $\mathrm{CO}$ (saturation of the strong and mild Brønsted and Lewis sites), the intensities of all the $v(\mathrm{CO})$ bands increase further and the position of the $v(\mathrm{CO} \ldots \mathrm{OH})$ is shifted to $2169 \mathrm{~cm}^{-1}$. This shift could indicate that the proportion of mild Brønsted sites has increased or that $\mathrm{CO}$ is adsorbed on milder Brønsted sites. The bands associated with weak Brønsted $\left(v(\mathrm{OH})=3745 \mathrm{~cm}^{-1}, v(\mathrm{CO} \ldots \mathrm{OH})=3650 \mathrm{~cm}^{-1}\right)$ and $v(\mathrm{CO})=2157$ $\mathrm{cm}^{-1}$ ) become the main bands and physisorbed CO is detected (band at $2140 \mathrm{~cm}^{-1}$ ). One can also note, whatever the $\mathrm{CO}$ loading, the absence of any band in the $\delta\left(\mathrm{OH}_{2}\right)$ range for this procedure.

Whatever the CO loading the spectra after the water exposure procedure ((b), W-723, dashed line) are radically different from those of FC-723. In the $v(\mathrm{CO})$ range, the $v(\mathrm{CO})$ bands at 2226 and $2190 \mathrm{~cm}^{-1}$ are notably weaker and only detected at high loading. This indicates that the amounts of Lewis sites (strong and mild) are significantly lowered by water adsorption. Simultaneously, the intensity of the $v(\mathrm{CO} \ldots \mathrm{OH})$ band is considerably increased whatever the loading and its position is shifted to higher wavenumber $\left(2176 \mathrm{~cm}^{-1}\right.$ for low and intermediate CO loading and $2170 \mathrm{~cm}^{-1}$ with a right shoulder at ca. $2174 \mathrm{~cm}^{-1}$ at high loading). This position is indicative of strong Brønsted sites (with strength similar, for example, to that of Brønsted sites in HY zeolites [2, 17]). This conclusion is confirmed by the analysis of the $v(\mathrm{OH})$ range where three bands are detected at low $\mathrm{CO}$ loading: two negative $v(\mathrm{OH})$ bands at 3688 and $3609 \mathrm{~cm}^{-1}$ and a broad band centred at ca $3440 \mathrm{~cm}^{-1}$ which appears to be the juxtaposition of two bands at ca. 3455 and $3410 \mathrm{~cm}^{-1}$. Increasing the CO loading leads to an increase of these four bands and to the observation of two more bands: a negative shoulder at $3715 \mathrm{~cm}^{-1}$ and a positive shoulder at ca. $3530 \mathrm{~cm}^{-1}$. These last two bands have already been observed with the previous pretreatment procedure and can therefore be assigned to native mild Brønsted sites. The position of the negative bands at 3688 and $3609 \mathrm{~cm}^{-1}$ and the 
simultaneous growth, in the $\delta\left(\mathrm{H}_{2} \mathrm{O}\right)$ range, of a negative band at $1604 \mathrm{~cm}^{-1}$ are consistent with $\mathrm{CO}$ adsorption on the sites responsible for the bands observed before $\mathrm{CO}$ adsorption at 3687 , 3609 and $1606 \mathrm{~cm}^{-1}$ (Figure 1) and assigned to water molecule interacting with Al Lewis sites. It is interesting to note the absence of any clearly visible positive band in the $\delta\left(\mathrm{H}_{2} \mathrm{O}\right)$ range that could be associated with the bending mode of OC...H-O-H...CO. This question has already been addressed by Garrone et al. [8] who suggested, based on ab initio calculation, that this band was expected to appear at $1628 \mathrm{~cm}^{-1}$ but could hardly be detected because its extinction coefficient was significantly lower than the one of the band associated with the bending mode of $\mathrm{H}-\mathrm{O}-\mathrm{H}$. We will come back to this point latter. This is a confirmation of the Brønsted acid character of these sites as already observed by Garrone et al.. If one takes into account the fact that these negative bands grow simultaneously with the positive bands at 3455 and $3410 \mathrm{~cm}^{-1}$, these two last bands are likely $v_{\mathrm{as}}(\mathrm{CO} \ldots \mathrm{OH})$ and $v_{\mathrm{s}}(\mathrm{CO} \ldots \mathrm{OH})$ due to the adsorption of two molecules of CO per chemisorbed water molecule (formation of OC...H-OH...CO). These values are close to those predicted by Garrone et all using theoretical calculations (3385 and $3440 \mathrm{~cm}^{-1}$ ) [8]. The shift of the $v(\mathrm{OH})$ upon adsorption of $\mathrm{CO}$ for these bands (which should be calculated as $\left.1 / 2\left(v_{\text {as }}(\mathrm{CO} \ldots \mathrm{OH})+v_{\mathrm{s}}(\mathrm{CO} \ldots \mathrm{OH})\right)-\left(v_{\mathrm{as}}(\mathrm{OH})+v_{\mathrm{s}}(\mathrm{OH})\right)\right)$ is ca. $-215 \mathrm{~cm}^{-1}$, which is significantly larger than the value calculated for the native mild Brønsted sites of the sample $\left(-168 \mathrm{~cm}^{-1}\right)$. Another interesting result of these experiments is that both mild and strong Lewis sites chemisorb $\mathrm{H}_{2} \mathrm{O}$ (the intensities of the bands of $\mathrm{CO}$ adsorbed on these two sites undergo a similar decrease in presence of water), but that only one type of chemisorbed water is observed (only one set of $v_{a s}(\mathrm{OH})$ and $v_{\mathrm{s}}(\mathrm{OH})$ ). One can propose two interpretations for this observation: either $\mathrm{H}_{2} \mathrm{O}$ is chemisorbed dissociatively on one of the type of Lewis sites (but it is unlikely as no new Al-OH band is detected) or, more likely, the two types of Lewis sites become identical after $\mathrm{H}_{2} \mathrm{O}$ adsorption. 
At low CO loading the spectra obtained after the Standard cooling procedure ((c) S723, solid line) have characteristics of both FC-723 and W-723 spectra. Indeed, in the v(CO) range, the bands characteristic of $\mathrm{CO}$ adsorbed on mild and strong Lewis sites are, as for FC723 , detected at 2230 and $2193 \mathrm{~cm}^{-1}$ but their intensities are lower than on the spectrum of FC-723. On the other side, the intensity of the $v(\mathrm{CO} \ldots \mathrm{OH})$ is stronger than for FC-723 and its position $\left(2175 \mathrm{~cm}^{-1}\right)$ is closer to the one observed for W-723 $\left(2176 \mathrm{~cm}^{-1}\right)$ than for FC-723 $\left(2172 \mathrm{~cm}^{-1}\right)$. In the $v(\mathrm{OH})$ range the bands assigned to water adsorbed on Lewis sites are detected at $3690,3608 \mathrm{~cm}^{-1}$ (negative bands) and $3440 \mathrm{~cm}^{-1}$ (together with the band assigned to the milder sites at $\left.3550 \mathrm{~cm}^{-1}\right)$ and in the $\delta\left(\mathrm{H}_{2} \mathrm{O}\right)$ range the characteristic band at $1605 \mathrm{~cm}^{-1}$ is also observed. However, upon increasing the $\mathrm{CO}$ loading the intensities of the bands corresponding to adsorbed water increase barely (this is particularly clear for the $\delta\left(\mathrm{H}_{2} \mathrm{O}\right)$ and, after saturation of the Brønsted and Lewis sites, the band assigned to the mild (native) Brønsted sites at $3550 \mathrm{~cm}^{-1}$ is clearly the main band (this is confirmed by the position of the $v(\underline{\mathrm{CO}} \ldots \mathrm{OH})$ band at saturation: $2169 \mathrm{~cm}^{-1}$ i.e. the same position as for FC-723). Nevertheless the presence of a much larger fraction of strong Brønsted sites following the Standard procedure than the Fast Cooling procedure is still evident when one compare, in the v(OH) range, the spectra after addition of $11 \mathrm{CO}$ pulses.

These three series of experiments clearly show the impact of water traces on the nature and strength of the acid sites detected by $\mathrm{CO}$ adsorption. They also show that the appropriate procedure to ensure the absence of $\mathrm{H}_{2} \mathrm{O}$ adsorption on the Lewis sites is a fast cooling of the sample from its pretreatment temperature (which is too high for water adsorption) to the measurement temperature (ca. $100 \mathrm{~K}$ ) without any intermediate cooling step to RT.

In order confirm the assignment proposed for the $v\left(\mathrm{OH}_{2}\right), v(\mathrm{OC} \ldots \mathrm{H}-\mathrm{O}-\mathrm{H} . . . \mathrm{CO})$ and $\delta\left(\mathrm{OH}_{2}\right)$ bands during this first series of experiments, we have performed a second set of experiments for which the wafer has been pretreated at a higher temperature (973 instead of 
$723 \mathrm{~K}$ ) in order to decrease the amount of native (strong and mild) Brønsted sites and increase the amount of Lewis sites by dehydroxylation (or by homolytic decomposition as suggested recently by Nash et al. [18]). The wafer was afterwards either rapidly cooled to 100K (FC-973) or exposed to water (W-973) or $\mathrm{D}_{2} \mathrm{O}$ (D-973) and subsequently treated under vacuum to remove physisorbed water.

The spectra prior to addition of $\mathrm{CO}$ are shown on figure 3 in the $v(\mathrm{OH}), v(\mathrm{OD})$ and $\delta\left(\mathrm{H}_{2} \mathrm{O}\right)$ ranges. As already reported for pretreatment at $723 \mathrm{~K}$, the spectra in absence of water ((a), FC-973, dotted line) present only one peak at $3752 \mathrm{~cm}^{-1}$, that can be assigned to isolated silanols (the shift to higher position of this peak after pretreatment at high temperature is consistent with previous reports [19]). The bump on the right side of this peak that was clearly visible after pre-treatment at $723 \mathrm{~K}$ (figure 1) and had been assigned to H-bonded silanols is not detected anymore which is consistent with a higher degree of dehydroxylation for the sample after high temperature pretreatment. As for W-723 (figure 1), the spectra after addition of $\mathrm{H}_{2} \mathrm{O}((\mathrm{c}), \mathrm{W}-973$, solid line) presents the three bands characteristic of water adsorption on the Lewis sites $\left(3693,3613\right.$ and $1604 \mathrm{~cm}^{-1}$ for respectively $v_{\mathrm{as}}\left(\mathrm{OH}_{2}\right), v_{\mathrm{s}}\left(\mathrm{OH}_{2}\right)$ and $\left.\delta\left(\mathrm{H}_{2} \mathrm{O}\right)\right)$. Their intensities are higher than on W-723, which is consistent with a higher amount of Lewis sites after high temperature pretreatment. Interestingly, the spectra after addition of $\mathrm{D}_{2} \mathrm{O}((\mathrm{b})$, D-973, dashed line) also shows, in the $v(\mathrm{OH})$ and $\delta\left(\mathrm{H}_{2} \mathrm{O}\right)$ ranges, the bands characteristic of $\mathrm{H}_{2} \mathrm{O}$ adsorption on the Lewis sites. As the $\mathrm{D}_{2} \mathrm{O}$ sample we used did not contain a significant amount of $\mathrm{H}_{2} \mathrm{O}$, this confirms that $\mathrm{H}_{2} \mathrm{O}$ traces present in the setup compete with $\mathrm{D}_{2} \mathrm{O}$ intentionally introduced for adsorption on the Lewis sites. Moreover, a third band is observed in the $v(\mathrm{OH})$ range at $3655 \mathrm{~cm}^{-1}$. The position of this last band which is almost at the exact average position of $v_{\text {as }}\left(\mathrm{OH}_{2}\right)$ and $v_{\mathrm{s}}\left(\mathrm{OH}_{2}\right)(3693+3612) / 2=3653 \mathrm{~cm}^{-1}$ allows us to assign it to $v(\mathrm{D}-\underline{\mathrm{OH}})$ (for water in the gas phase the half sum of $v_{\mathrm{as}}\left(\mathrm{OH}_{2}\right)$ and $v_{\mathrm{s}}\left(\mathrm{OH}_{2}\right)$ is $3706.5 \mathrm{~cm}^{-1}$ compared to $v(\mathrm{D}-\mathrm{OH})=3707.5 \mathrm{~cm}^{-1}$ [20]). This HOD could, for example, be formed by 
reaction of $\mathrm{D}_{2} \mathrm{O}$ with $\mathrm{H}_{2} \mathrm{O}$ adsorbed on the Lewis sites. The presence of adsorbed HOD is confirmed by the band at $1418 \mathrm{~cm}^{-1}$ in the bending mode range whose position is consistent with $\delta(\mathrm{HOD})\left(\delta(\mathrm{HOD})=1403.5 \mathrm{~cm}^{-1}\right.$ in the gas phase [20]). This result is also a confirmation of the attribution proposed by Garrone et al. of the bands at ca. 3690 and $3610 \mathrm{~cm}^{-1}$ to $v_{\mathrm{as}}\left(\mathrm{OH}_{2}\right)$ and $v_{\mathrm{s}}\left(\mathrm{OH}_{2}\right)$ of $\mathrm{H}_{2} \mathrm{O}$ shifted by adsorption on Lewis sites [8]. The spectra of D-973 shows some similarities in the $v(\mathrm{OD})$ compared to the $v(\mathrm{OH})$. In this range four bands are detected at 2764, 2749, 2689 and $2637 \mathrm{~cm}^{-1}$. The first band can be assigned to Si-OD of silica like domains (reported at $2761 \mathrm{~cm}^{-1}$, [21]). For the other three, the half sum of the positions of the first and third bands $(2746+2637)=2693 \mathrm{~cm}^{-1}$ compares rather well with the position of the second band $\left(2689 \mathrm{~cm}^{-1}\right)$. These three bands can therefore be assigned to $v_{\mathrm{as}}\left(\mathrm{OD}_{2}\right), \mathrm{v}(\underline{\mathrm{DO}}-\mathrm{H})$ and $v_{\mathrm{s}}\left(\mathrm{OD}_{2}\right)$ (in the gas phase the positions of $v_{\mathrm{as}}\left(\mathrm{OD}_{2}\right)$ and $v_{\mathrm{s}}\left(\mathrm{OD}_{2}\right)$ are 2787.7 and 2671.7 $\mathrm{cm}^{-1}$, half sum $2729.7 \mathrm{~cm}^{-1}$ compared to 2723.7 for $v(\underline{\mathrm{DO}}-\mathrm{H})$ [22]).

The difference spectra after CO addition on FC-973 ((a),dotted black line), W-973 ((b), solid black line) $(v(\mathrm{OH})$ and $v(\mathrm{CO})$ ranges) and D-973 ((c), solid gray line) ( $(\mathrm{OD})$ range) after saturation of the strong and mild Lewis and Brønsted sites (addition of 11 pulses of CO, ca. $5 \mu \mathrm{mol}$ of $\mathrm{CO}$ ) are shown on figure 4. For comparison, the spectrum of FC-723 is also shown on this figure ((d), dashed black line). The comparison of FC-723 and FC-973, shows an increase in the amount of mild and strong Lewis sites ( $v(\mathrm{CO})$ at 2232 and $\left.2188 \mathrm{~cm}^{-1}\right)$ and a decrease in the amount of Brønsted sites $\left(v(\underline{\mathrm{CO}} \ldots \mathrm{OH})=2169 \mathrm{~cm}^{-1}\right)$ which are consistent with the transformation, at least partial, of Brønsted sites in Lewis sites by high temperature dehydroxylation. The loss of most of the Brønsted sites in FC-973 sites is confirmed by the analysis of the $v(\mathrm{OH})$ range for this spectrum, where only mild Brønsted site are detected $\left(v(\mathrm{CO} \ldots \underline{\mathrm{OH}})=3580 \mathrm{~cm}^{-1}\right)$ and in smaller quantity compared to FC-723. Addition of $\mathrm{H}_{2} \mathrm{O}$, leads, as observed after pretreatment at $723 \mathrm{~K}$, to a decrease in the amount of mild and strong Lewis 
sites. This not only confirms the adsorption of $\mathrm{H}_{2} \mathrm{O}$ on these sites, but also allows to clearly identify the bands associated with $\mathrm{H}_{2} \mathrm{O}$ adsorbed on the Lewis sites: $v_{\text {as }}\left(\mathrm{OH}_{2}\right)=3698 \mathrm{~cm}^{-1}$ $v_{\mathrm{s}}\left(\mathrm{OH}_{2}\right)=3612 \mathrm{~cm}^{-1}$ and $\delta\left(\mathrm{H}_{2} \mathrm{O}\right)=1604 \mathrm{~cm}^{-1}$ (not shown). This experiment also confirms the presence of two bands of $\mathrm{OH}$ in interaction with $\mathrm{CO}$ for these sites: $v(\mathrm{CO} \ldots \mathrm{OH})=3452 \mathrm{~cm}^{-1}$ and $3421 \mathrm{~cm}^{-1}$ that most probably correspond to asymmetric and symmetric stretching of OC...H-O-H...CO, and the very strong acidity of these sites as testified by the position of the $v(\mathrm{CO})$ at $2177 \mathrm{~cm}^{-1}$ i.e. at the same position as, for example a $\mathrm{HY}$ zeolite $(\mathrm{Si} / \mathrm{Al}=5.4)$ [2]. Moreover the position of the corresponding bands in presence of $\mathrm{D}_{2} \mathrm{O}$ can be identified at 2737 and $2638 \mathrm{~cm}^{-1}$ (antisymmetric and symmetric stretching of $\mathrm{D}_{2} \mathrm{O}$ ) and the remaining negative bands can be assigned to $v(\underline{\mathrm{DO}}-\mathrm{H})\left(2688 \mathrm{~cm}^{-1}\right)$ and $v(\mathrm{Si}-\underline{\mathrm{OD}})$ of Si-OD from silica like domains $\left(2764 \mathrm{~cm}^{-1}\right)$. A band corresponding to OD in interaction with $\mathrm{CO}$ is located at $2536 \mathrm{~cm}^{-1}$. Considering the higher intensity of $v(\underline{\mathrm{DO}}-\mathrm{H})$ compared to $v_{\mathrm{as}}(\underline{\mathrm{D}-\mathrm{O}-\mathrm{D}})$ and $\mathrm{v}_{\mathrm{a}}(\underline{\mathrm{D}-\mathrm{O}-}$ D), the position of this band is likely related to $v(\mathrm{CO} \ldots$ DO-H) and the weak shoulders on both side could be due to $v_{\mathrm{as}}(\mathrm{OC} \ldots \underline{\mathrm{D}-\mathrm{O}-\mathrm{D}} \ldots \mathrm{CO})$ and $v_{\mathrm{s}}(\mathrm{OC} \ldots \underline{\mathrm{D}-\mathrm{O}-\mathrm{D}} \ldots \mathrm{CO})$, but the exact positions of these bands cannot be determined.

According to the theoretical calculation reported by Garrone et al. [8], the first and the second molecules of $\mathrm{CO}$ adsorb on the water molecule with very similar heat of adsorption ($15 \mathrm{~kJ} \cdot \mathrm{mol}^{-1}$ for the first $\mathrm{CO}$ molecule and $-14 \mathrm{~kJ}^{\mathrm{mol}}{ }^{-1}$ for the second) but the adsorption of the first CO molecule reflects slightly stronger sites $\left(\Delta v(\mathrm{OH})=298 \mathrm{~cm}^{-1}\right.$ for a single CO molecule per $\mathrm{H}_{2} \mathrm{O}$ vs. $239 \mathrm{~cm}^{-1}$ for two molecules of $\mathrm{CO}$ ). We checked whether we could detect this band for W-973 and D-973 by performing an experiment at low CO coverage (addition of $0.1 \mu \mathrm{mol}$ of $\mathrm{CO}$ ) and also by measuring a spectrum after saturation followed by desorption at $10^{-5}$ Torr. The spectra in the $v(\mathrm{OH})$ and $v(\mathrm{CO})$ ranges (W-973) and in the $v(\mathrm{OD})$ range (D-973) are shown on figure 5. To facilitate the comparison the intensities of the 
spectra at low CO coverage (dotted lines) have been multiplied by a factor of ca. 10. In the $v(\mathrm{OH})$ and $v(\mathrm{OD})$ ranges the negative bands characteristics of adsorbed $\mathrm{H}_{2} \mathrm{O}\left(\mathrm{D}_{2} \mathrm{O} \& \mathrm{HOD}\right)$ are clearly visible on all spectra and at the same positions as those reported after saturation of the Brønsted and Lewis sites, but the $v(\mathrm{CO} \ldots \underline{\mathrm{OH}})$ and $v(\mathrm{CO} \ldots \underline{\mathrm{OD}})$ bands of strong Brønsted sites are shifted to lower wavenumbers with regards to the spectra recorded at saturation as they are observed respectively at 3395 and $2508 \mathrm{~cm}^{-1}$ (compared to $(3452+3421) / 2=3436$ and $\left.2536 \mathrm{~cm}^{-1}\right)$. Moreover, the position of the $v(\underline{\mathrm{CO}} \ldots \mathrm{OH})$ band is shifted to $2180 \mathrm{~cm}^{-1}$ (compared to $2177 \mathrm{~cm}^{-1}$ at saturation). This indicates a very strong acidity for the water molecules adsorbed on the Lewis sites at low CO coverage and is consistent with the adsorption of a single $\mathrm{CO}$ molecule per water molecule at low coverage. Moreover the similarity between the spectra at low coverage and after saturation followed by desorption at $10^{-5}$ Torr indicates that it is possible to selectively remove one of the $\mathrm{CO}$ molecule under vacuum. When a single molecule of $\mathrm{CO}$ is adsorbed per water molecule, a band corresponding to the free $\mathrm{OH}(\underline{\mathrm{H}-\mathrm{O}}-$ H...CO $)$ is expected to appear. Although the position is similar to the one of $v(\mathrm{CO} \ldots \mathrm{OH})$ of silanols, we can propose that this $\mathrm{OH}$ is responsible for the narrow band at $3676 \mathrm{~cm}^{-1}$, as no band characteristic of $\mathrm{CO}$ adsorbed on silanol is detected in the $v(\mathrm{CO})$ range on these spectra and this position would be consistent with the position predicted for this band by Garrone et al $\left(3674 \mathrm{~cm}^{-1}\right)[8]$.

As mentioned above, the adsorption of $\mathrm{CO}$ on $\mathrm{Al}\left[\mathrm{OH}_{2}\right.$ should lead, in the $\delta\left(\mathrm{H}_{2} \mathrm{O}\right)$ range, not only to the negative band at $1604 \mathrm{~cm}^{-1}$ but also to a positive band (corresponding to the bending mode of $\mathrm{H}-\mathrm{O}-\mathrm{H} . . . \mathrm{CO}$ or $\mathrm{CO} . . \mathrm{H}-\mathrm{O}-\mathrm{H} . . . \mathrm{CO})$. The difficulty to observe these positive bands has been already discussed by Garrone et al. [8] and assigned, based on ab initio calculation, to their weak extinction coefficients and close proximity to the $\delta\left(\mathrm{Al} \square \underline{\mathrm{OH}_{2}}\right)$ (predicted values: $44 \mathrm{~cm} . \mu \mathrm{mol}^{-1} / 1628 \mathrm{~cm}^{-1}$ for $\mathrm{Al} \mathrm{COH}_{2}(\mathrm{CO})_{2}, 78 \mathrm{~cm} . \mu \mathrm{mol}^{-1} / 1619 \mathrm{~cm}^{-1}$ for $\mathrm{Al}\left[\mathrm{OH}_{2} \mathrm{C}\right.$, and $131 \mathrm{~cm} . \mu \mathrm{mol}^{-1} / 1605 \mathrm{~cm}^{-1} 1$ for $\mathrm{Al}^{\circ} \mathrm{OH}_{2}$ ). Nevertheless the absence of these 
bands could also be regarded as indicative of a dissociation of adsorbed water molecules upon $\mathrm{CO}$ adsorption. $\left(=\left(\mathrm{OH}_{2}\right) \mathrm{Al}-\mathrm{O}-\mathrm{Si} \equiv \rightarrow=(\mathrm{OH}) \mathrm{Al}-\mathrm{OH}-\mathrm{Si} \equiv\right)$. In order to discriminate between these two possibilities, we have examined the 1800-1400 range of the W-973 difference spectra (figure 6) after saturation of all the acid sites ((a), dotted line) and after evacuation at $10^{-5}$ torr ((b), solid line). A weak positive band is observed on the two spectra -located at 1623 $\mathrm{cm}^{-1}$ after evacuation (i.e. at low CO loading) it is positioned at $1654 \mathrm{~cm}^{-1}$ and broader at high CO loading, which supports the assignment previously proposed by Garrone et al.

The attributions of the FTIR bands discussed in this work have been summed up in Table 1.

\section{I.6. Conclusion}

The $\mathrm{CO}$ adsorption experiments reported in this paper clearly show the impact of water on the nature and strength of the acid sites detected by $\mathrm{CO}$ adsorption. They confirm the adsorption of $\mathrm{CO}$ on Lewis sites and indicate that both strong and mild Lewis sites are concerned and that they are likely both transformed in identical strong acid sites upon adsorption of water. These experiments also show that water traces present in the set-up can modify significantly the distribution of Lewis and Brønsted sites and increase substantially the amount of strong Brønsted acid sites detected by $\mathrm{CO}$ adsorption. Indeed, although strong Brønsted sites are probably natively present in ASA, the present work demonstrates that care must be taken during the evaluation of the amount of these strong Brønsted sites, because the strong acid sites formed by adsorption of water may contribute significantly to the total amount of strong Brønsted sites. Adsorption of water, unbeknownst to the experimenter, can therefore give a false impression of the strength of the acid sites of ASA and complicate the determination of their true nature. It is therefore important to have a clear signature for unwanted water readsorption: although the presence of water on the Lewis sites is associated with several bands $\left(3693,3613\right.$ and $1604 \mathrm{~cm}^{-1}$ for respectively $v_{\mathrm{as}}\left(\mathrm{OH}_{2}\right), v_{\mathrm{s}}\left(\mathrm{OH}_{2}\right)$ and $\left.\delta\left(\mathrm{H}_{2} \mathrm{O}\right)\right)$ 
some of these bands may be difficult to detect because their position is too close to other FTIR band occurring during a $\mathrm{CO}$ adsorption experiment. This is in particular the case for the band at $3696 \mathrm{~cm}^{-1}$ that can be easily masked by the positive (and very strong) band of $v(\mathrm{CO} \ldots \mathrm{OH})$ of the silanols of the silica-like domains. However (at least for $\mathrm{CO}$ adsorption) the $\delta\left(\mathrm{H}_{2} \mathrm{O}\right)$ band should constitute a clear indication of the presence of adsorbed water as it occurs in a spectral range where no other band is expected in the difference spectra. This band should therefore be used as fingerprint of the presence of adsorbed water.

As the elimination of every water traces in the set-up is probably impossible, we have proposed an alternative procedure that ensure the absence of $\mathrm{CO}$ adsorption (as evidenced by the absence of the $\delta\left(\mathrm{H}_{2} \mathrm{O}\right)$ band): fast cooling of the sample from its pretreatment temperature (which is too high for water adsorption) to the measurement temperature (ca. $100 \mathrm{~K}$ ) prevents the desorption of water from the set up in the vicinity of the wafer, whereas an intermediate cooling step from pretreatment temperature to RT is favourable to water adsorption.

In order to determine precisely the positions of the bands assigned to $\mathrm{H}_{2} \mathrm{O}$ and $\mathrm{D}_{2} \mathrm{O}$ adsorbed on Lewis sites, a second series of experiment has been performed on a highly dehydroxylated ASA (to decrease the amount of native Brønsted sites and increase the amount of Lewis sites, the sites responsible for water adsorption). The positions of the $v(\mathrm{CO})$, $v(\mathrm{OH}), v(\mathrm{OD})$ bands for water/ $\mathrm{D}_{2} \mathrm{O}$ adsorbed on Lewis sites are summed up in Table 1 and could be used for a new evaluation of previously published results taking into account the possibility of water adsorption. Moreover, this experiment has shown that severe dehydroxylation followed by rehydration transforms the weak native Brønsted sites $\left(v(\mathrm{CO} \ldots \mathrm{OH})=2172 \mathrm{~cm}^{-1}\right)$, in much stronger sites $\left(v(\mathrm{CO} \ldots \mathrm{OH})=2180-2178 \mathrm{~cm}^{-1}\right.$ with an acidity strength similar to that of zeolites. 


\section{I.7. Acknowledgments}

This work was carried out in the framework of the Japanese-French GDRI ECSAW.

The authors thank the CNRS and the AIST for supporting this research.

\section{I.8. References}

[1] K. Gora-Marek and J. Datka, Appl. Catal., A, 302 (2006) 104.

[2] G. Crepeau, V. Montouillout, A. Vimont, L. Mariey, T. Cseri and F. Mauge, J. Phys. Chem. B, 110 (2006) 15172.

[3] M. Trombetta, G. Busca, M. Lenarda, L. Storaro and M. Pavan, Appl. Catal., A, 182 (1999) 225.

[4] M. Trombetta, G. Busca, S. Rossini, V. Piccoli, U. Cornaro, A. Guercio, R. Catani and R.J. Willey, J. Catal., 179 (1998) 581.

[5] C. Chizallet and P. Raybaud, Angewt Chem., 48 (2009) 2891.

[6] M.R. Basila, T.R. Kantner and K.H. Rhee, J. Phys. Chem., 68 (1964) 3197.

[7] M.R. Basila and T.R. Kantner, J. Phys. Chem., 70 (1966) 1681.

[8] E. Garrone, B. Onida, B. Bonelli, C. Busco and P. Ugliengo, J. Phys. Chem. B, 110 (2006) 19087.

[9] J.N. Kondo, R. Nishitani, E. Yoda, T. Yokoi, T. Tatsumi and K. Domen, Phys. Chem. Chem. Phys., 12 (2010) 11576.

[10] F. Leydier, C. Chizallet, A. Chaumonnot, M. Digne, E. Soyer, A.-A. Quoineaud, D. Costa and P. Raybaud, J. Catal., 284 (2011) 215.

[11] W. Daniell, N.Y. Topsoe and H. Knoezinger, Langmuir, 17 (2001) 6233.

[12] E.J.M. Hensen, D.G. Poduval, D. Ligthart, J.A.R. van Veen and M.S. Rigutto, J. Phys. Chem. C, 114 (2010) 8363.

[13] E.J.M. Hensen, D.G. Poduval, P. Magusin, A.E. Coumans and J.A.R. van Veen, J. Catal., 269 (2010) 201.

[14] S. Handjani, S. Dzwigaj, J. Blanchard, E. Marceau, J.-M. Krafft and M. Che, Top. Catal., 52 (2009) 334.

[15] N.N. Trukhan, A.A. Panchenko, E. Roduner, M.S. Mel'guno, O.A. Kholdeeva, J. Mrowiec-Bialon and A.B. Jarzebski, Langmuir, 21 (2005) 10545.

[16] J.S. Daluz, A. Kocak and R.B. Metz, J. Phys. Chem. A, 116 (2012) 1344.

[17] O. Cairon and T. Chevreau, J. Chem. Soc, Faraday Trans., 94 (1998) 323.

[18] M.J. Nash, A.M. Shough, D.W. Fickel, D.J. Doren and R.F. Lobo, Journal of the American Chemical Society, 130 (2008) 2460.

[19] P. Hoffmann and E. Knözinger, Surf. Sci., 188 (1987) 181.

[20] N.F. Zobov, O.L. Polyansky, C.R. Le Sueur and J. Tennyson, Chemical Physics Letters, 260 (1996) 381.

[21] A. Burneau and C. Carteret, Phys. Chem. Chem. Phys., 2 (2000) 3217.

[22] R. Lemus, Journal of Molecular Spectroscopy, 225 (2004) 73.

\section{I.9. Figure captions}

Figure 1: IR spectra of FC-723 (a), S-723 (b) and W-723 (c) in the $v(\mathrm{OH})(3800-3200$ $\left.\mathrm{cm}^{-1}\right)$ and $\delta\left(\mathrm{H}_{2} \mathrm{O}\right)\left(1700-1500 \mathrm{~cm}^{-1}\right)$ ranges. 
Figure 2: IR difference spectra after CO adsorption on FC-723 ((a), dotted line), S-723 ((b), solid black line) and W-723 ((c), dashed line) in the $v(\mathrm{OH})\left(3800-3200 \mathrm{~cm}^{-1}\right), v(\mathrm{CO})$ (1700-1500 $\left.\mathrm{cm}^{-1}\right)$ and $\delta\left(\mathrm{H}_{2} \mathrm{O}\right)\left(1700-1500 \mathrm{~cm}^{-1}\right)$ ranges: (I) after adsorption of $0.45 \mu \mathrm{mol}$ of $\mathrm{CO}$ ); (II) after adsorption of $0.9 \mu \mathrm{mol}$; (III) after adsorption of $5 \mu \mathrm{mol}$ of $\mathrm{CO}$ (saturation of all, mild and strong, Lewis and Brønsted, sites).

Figure 3: IR spectra of FC-973 ((a), dotted line), D-973 ((b), dashed line) and W-973 $\left((\mathrm{c})\right.$, solid line) in the $v(\mathrm{OH})\left(3800-3200 \mathrm{~cm}^{-1}\right), v(\mathrm{OD})$ range $\left(2800-2500 \mathrm{~cm}^{-1}\right)$ and $\delta\left(\mathrm{H}_{2} \mathrm{O}\right)$ (1700-1500 $\left.\mathrm{cm}^{-1}\right)$ ranges.

Figure 4: IR difference spectra after adsorption of $5 \mu \mathrm{mol}$ of $\mathrm{CO}$ (saturation of all, mild and strong, Lewis and Brønsted, sites) on: FC-973 ((a) dotted black line), W-973 ((b) solid black line), FC-723 ((d) dashed black line) in the $v(\mathrm{OH})\left(3800-3200 \mathrm{~cm}^{-1}\right)$ and $v(\mathrm{CO})$ (1700-1500 $\left.\mathrm{cm}^{-1}\right)$ ranges and of D-973 ((c) solid gray line) in the $v(\mathrm{OD})$ range (2800-2500 $\left.\mathrm{cm}^{-1}\right)$.

Figure 5: IR difference spectra after adsorption of $0.1 \mu \mathrm{mol}$ of $\mathrm{CO}((\mathrm{a})$, (b), dotted lines) and after saturation of the Lewis and Brønsted sites followed by desorption under vacuum at $10^{-5}$ Torr ((c), (d) solid lines) in the $v(\mathrm{OH})\left(3800-3200 \mathrm{~cm}^{-1}\right)$ and $v(\mathrm{CO})(1700$ $\left.1500 \mathrm{~cm}^{-1}\right)$ ranges (W-973) and in the $v(\mathrm{OD})$ range $\left(2800-2500 \mathrm{~cm}^{-1}\right)(\mathrm{D}-973)$. The spectra after addition of $0.1 \mu \mathrm{mol}$ of $\mathrm{CO}$ have been multiplied by 10 to facilitate the comparison (the absorbance scales refer to the spectra (b) \& (d) ie. after saturation)

Figure 6: IR difference spectra of W-973 in the 1800-1400 range after saturation of the acid sites ((a), dotted line) followed by desorption under vacuum at $10^{-5}$ torr ((b), solid line) 
- Table 1: Assignment of the FTIR bands associated with Brønsted sites

\begin{tabular}{|c|c|c|c|c|}
\hline $\begin{array}{c}v(\mathrm{OX})^{(\mathrm{a})} \\
\left(\mathrm{cm}^{-1}\right)\end{array}$ & $\begin{array}{c}v\left(\mathrm{CO} \ldots \underline{\mathrm{OX})}^{(\mathrm{a})}\right. \\
\left(\mathrm{cm}^{-1}\right)\end{array}$ & $\begin{array}{c}\Delta v(\mathrm{OX})^{(\mathrm{a})} \\
\left(\mathrm{cm}^{-1}\right)\end{array}$ & $\begin{array}{c}v(\underline{\mathrm{CO}} \ldots \mathrm{OX})^{(\mathrm{a})} \\
\left(\mathrm{cm}^{-1}\right)\end{array}$ & assignment \\
\hline 3745 & 3650 & 95 & 2156 & $\begin{array}{l}\text { Si-OH, weak Brønsted } \\
\text { sites }\end{array}$ \\
\hline 2764 & $\begin{array}{l}\text { Not observed } \\
\text { (expected at 2698) }\end{array}$ & & 2156 & $\begin{array}{l}\text { Si-OD, weak Brønsted } \\
\text { sites }\end{array}$ \\
\hline 3718 & 3550 & 160 & 2169 & $\begin{array}{l}\text { Mild (native) Brønsted } \\
\text { sites (possibly silanols in } \\
\text { close proximity with } \\
\text { Lewis Al) }\end{array}$ \\
\hline ? & 3450 & & ? & $\begin{array}{l}\text { Moderate/Strong (native) } \\
\text { Brønsted sites }\end{array}$ \\
\hline $\begin{array}{l}3690 \quad\left(v_{\mathrm{as}}\right) \\
3610\left(v_{\mathrm{s}}\right)\end{array}$ & $\begin{array}{lll}3450 & \left(v_{\mathrm{as}}\right) & \& 3420 \\
& & \\
\left(v_{\mathrm{s}}\right) & & \end{array}$ & 215 & 2177 & $\begin{array}{l}\text { Strong Brønsted sites } \\
\text { formed by adsorption of } \\
\mathrm{H}_{2} \mathrm{O} \text { on Lewis sites at high } \\
\text { coverage (two CO per } \\
\text { water molecule) }\end{array}$ \\
\hline $\begin{array}{l}2740 \quad\left(v_{\mathrm{as}}\right) \\
\& 2637\left(v_{\mathrm{s}}\right)\end{array}$ & $\begin{array}{l}\text { Accurate position } \\
\text { undetermined }\end{array}$ & & 2177 & $\begin{array}{l}\text { Strong Brønsted sites } \\
\text { formed by adsorption of } \\
\mathrm{D}_{2} \mathrm{O} \text { on Lewis sites at high } \\
\text { coverage (two CO per } \\
\text { water molecule) }\end{array}$ \\
\hline 2689 & 2536 & 153 & 2177 & $\begin{array}{l}\text { Strong Brønsted sites } \\
\text { formed by adsorption of }\end{array}$ \\
\hline
\end{tabular}




\begin{tabular}{|c|c|c|c|c|}
\hline & & & & $\begin{array}{l}\text { HOD on Lewis sites at } \\
\text { high coverage (two CO per } \\
\text { water molecule) }\end{array}$ \\
\hline $\begin{array}{l}3690\left(v_{\mathrm{as}}\right) \\
\& 3610\left(v_{\mathrm{s}}\right)\end{array}$ & $\begin{array}{l}3396+(3676 \text { for } \\
\text { the free } \mathrm{OH})\end{array}$ & 254 & 2180 & $\begin{array}{l}\text { Strong Brønsted sites } \\
\text { formed by adsorption of } \\
\mathrm{H}_{2} \mathrm{O} \text { on Lewis sites at high } \\
\text { coverage (one CO per } \\
\text { water molecule) }\end{array}$ \\
\hline 2689 & 2508 & 181 & 2180 & $\begin{array}{l}\text { Strong Brønsted sites } \\
\text { formed by adsorption of } \\
\text { HOD on Lewis sites at } \\
\text { high coverage (one CO per } \\
\text { water molecule) }\end{array}$ \\
\hline
\end{tabular}

${ }^{\text {(a) }}$ where X stands for H or D 


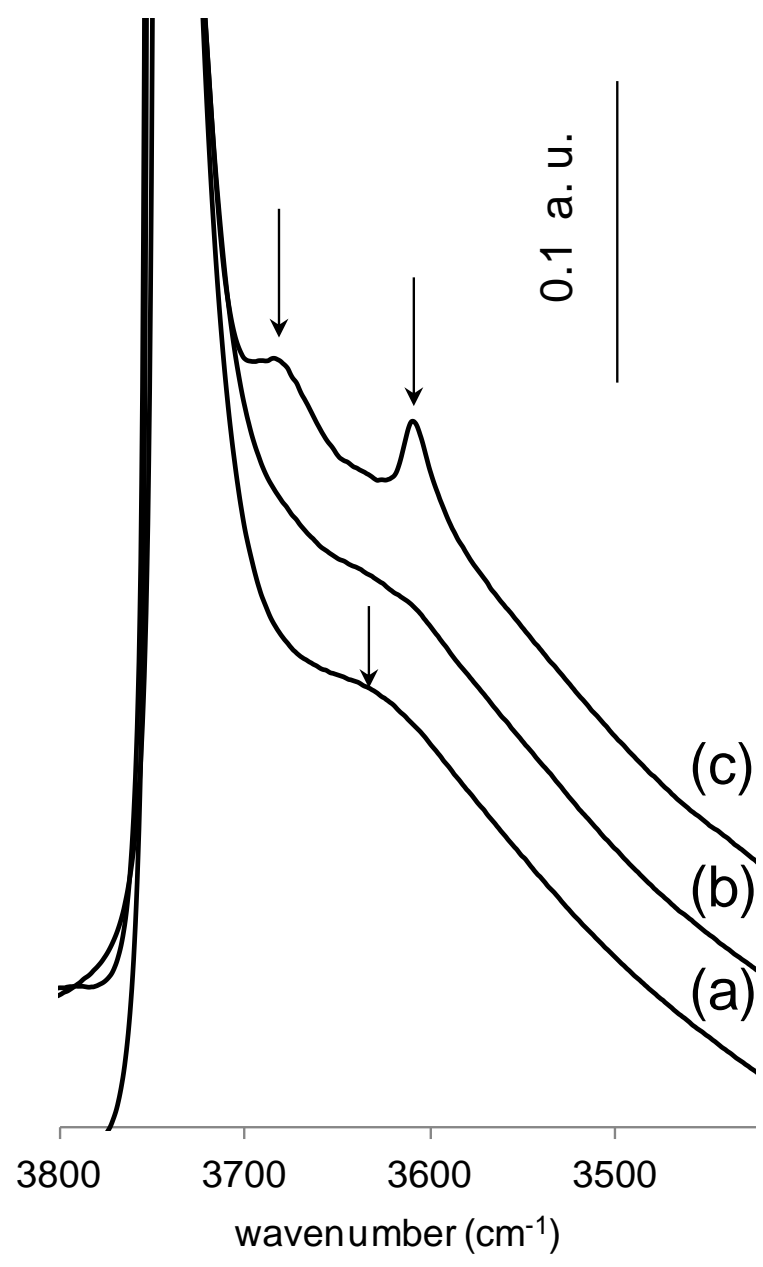

Figure 1
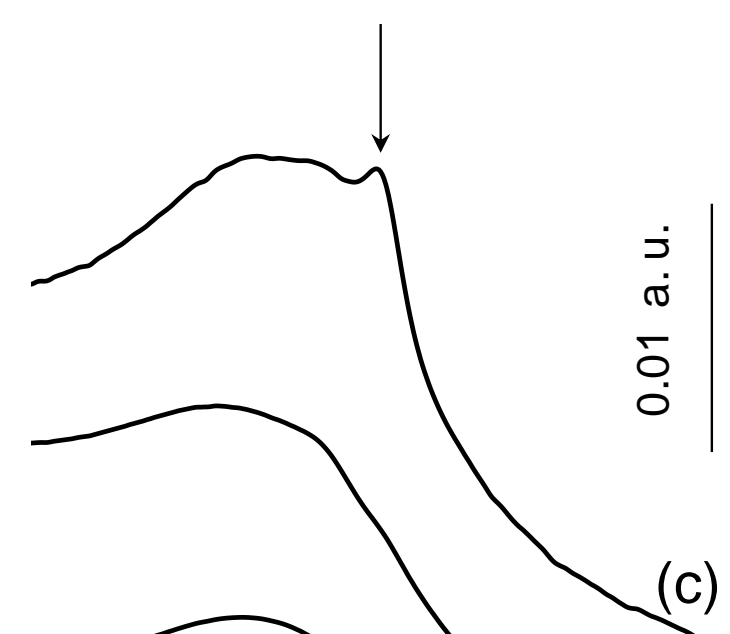

(b)

(a)

1700

1650

1600

1550 

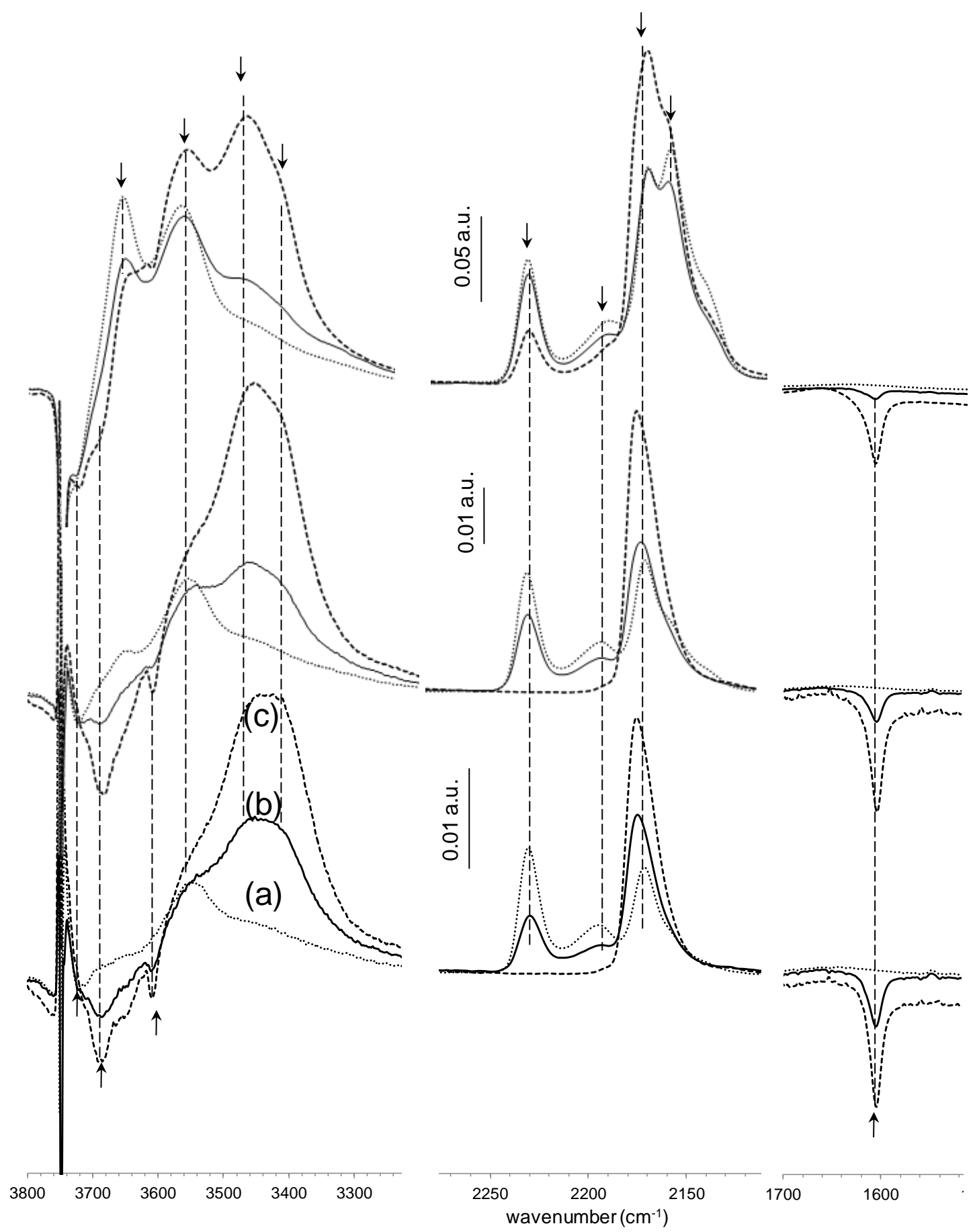

(III)

(II)

Figure 2 


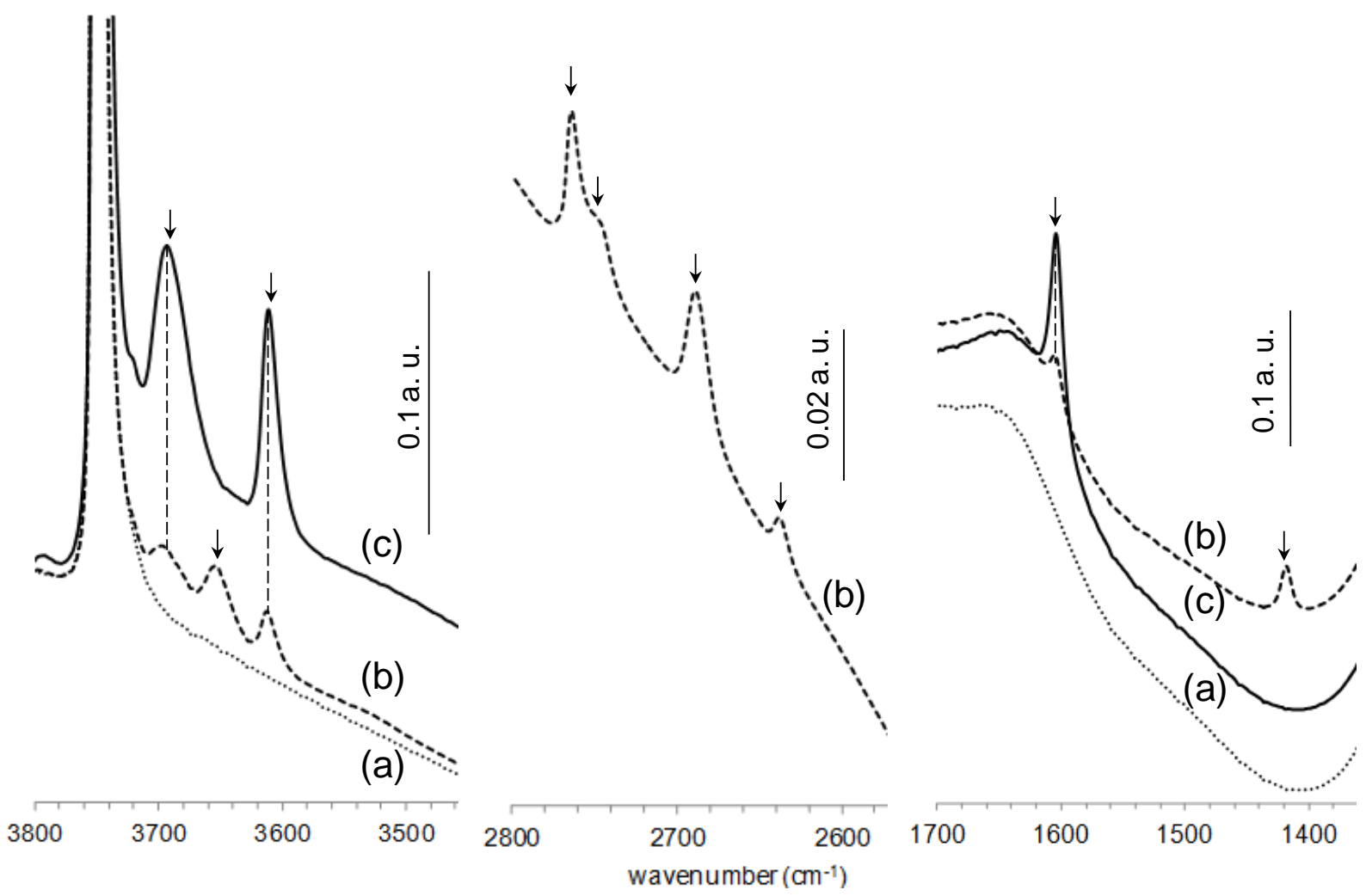

Figure 3 

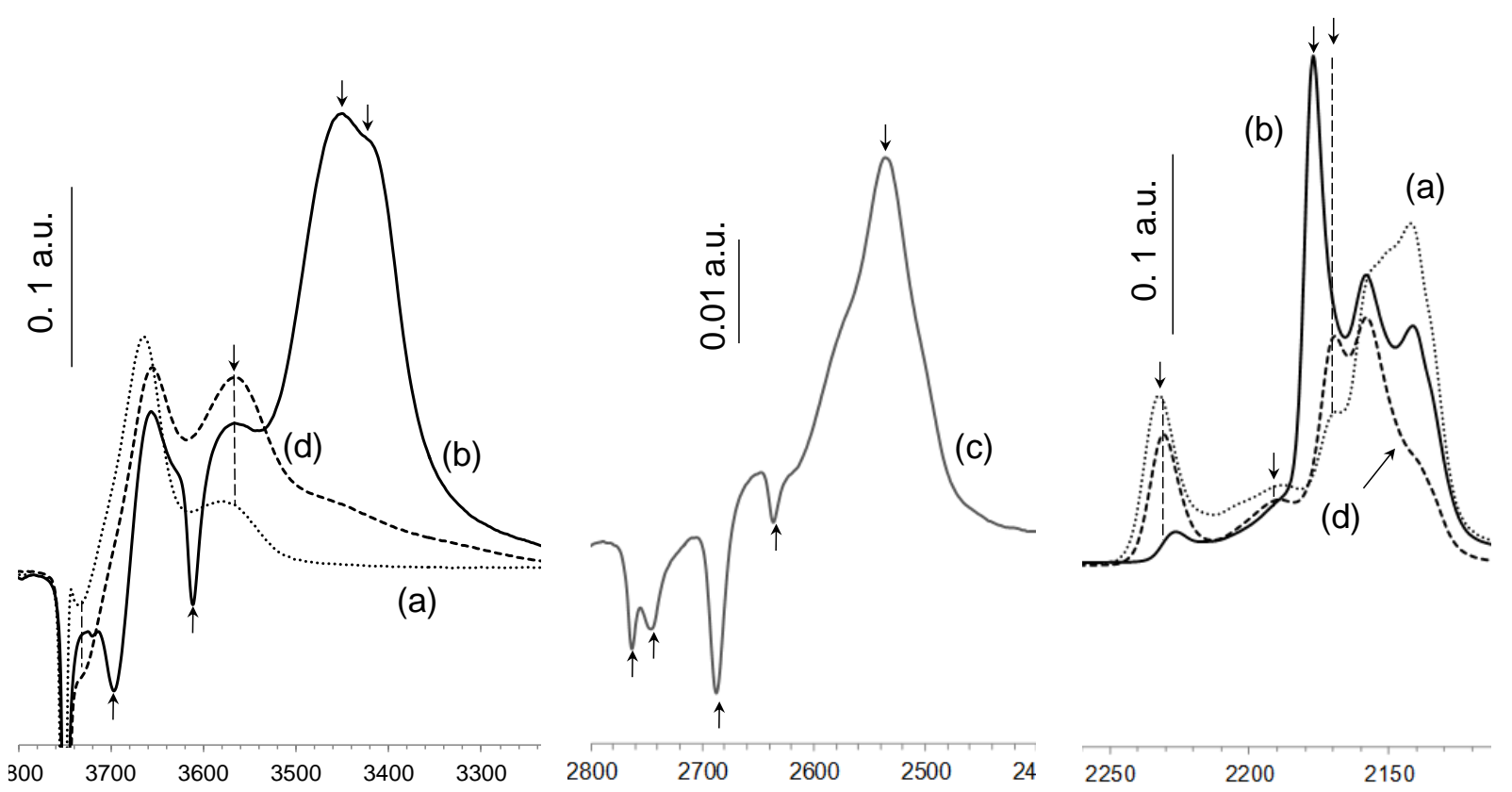

Figure 4 


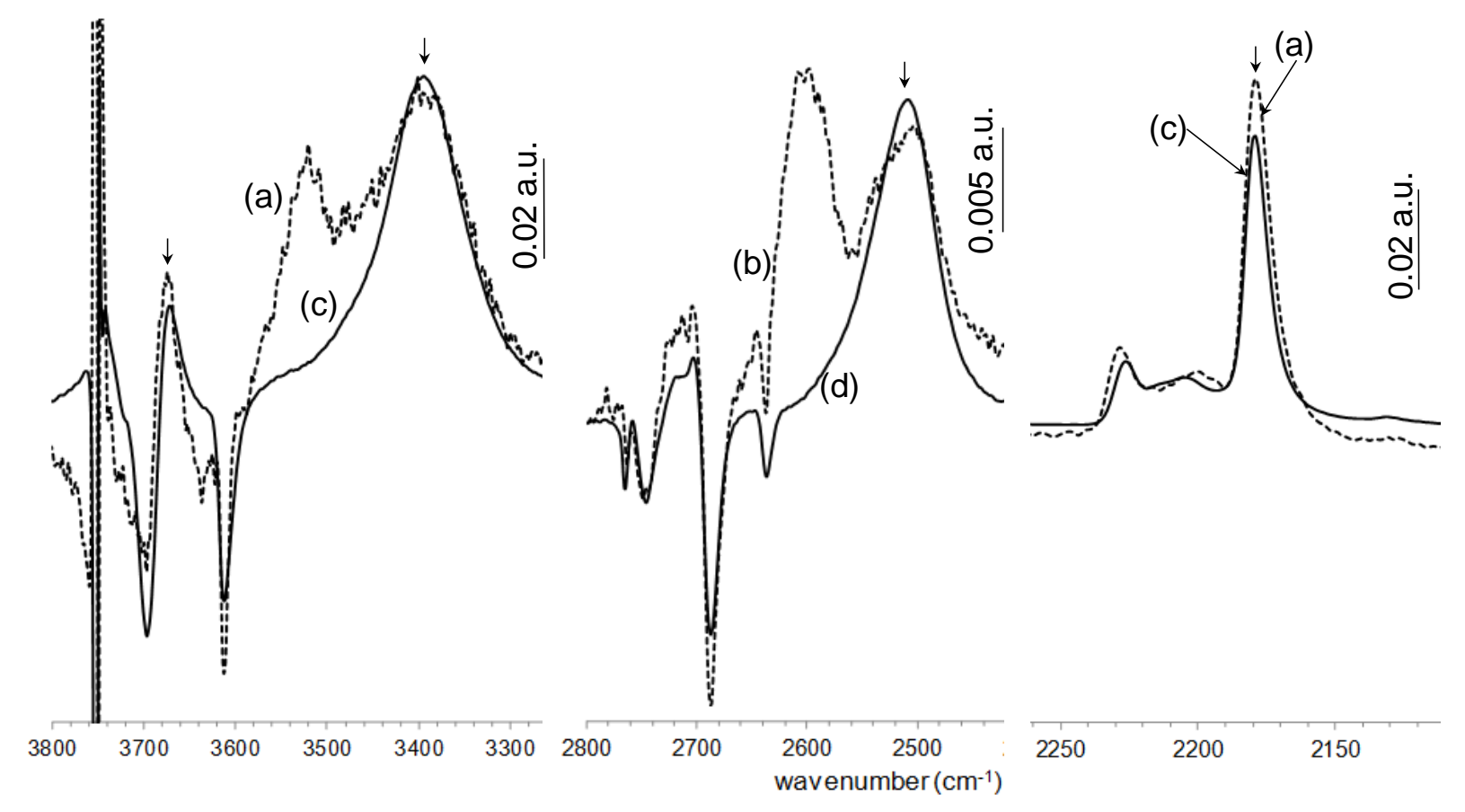

Figure 5 


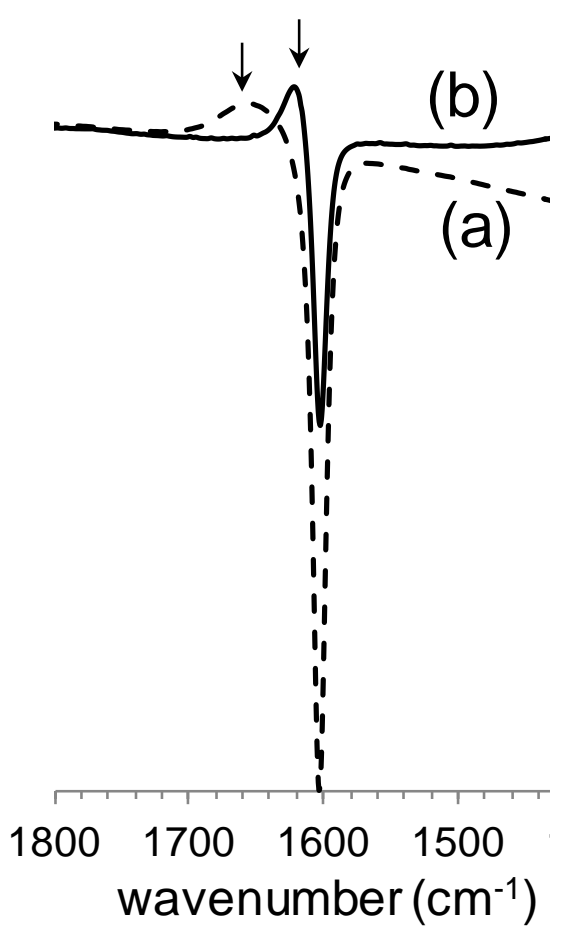

Figure 6 


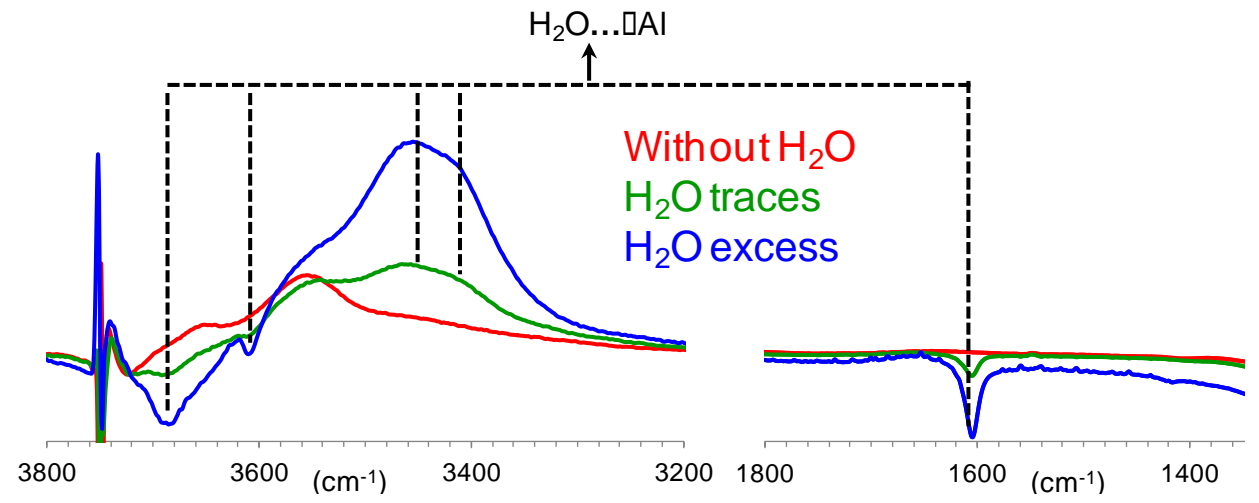

Graphical abstract 